\title{
The Role of microRNAs in the Diagnosis and Treatment of Pancreatic Adenocarcinoma
}

\author{
Maria Diab ${ }^{1}$, Irfana Muqbil ${ }^{2}$, Ramzi M. Mohammad ${ }^{2}$, Asfar S. Azmi ${ }^{2}$ and Philip A. Philip ${ }^{2, *}$ \\ 1 Department of Internal Medicine, School of Medicine, Wayne State University, Detroit, MI 48201, USA; \\ diab.maria@gmail.com \\ 2 Department of Oncology, Karmanos Cancer institute, Wayne State University, Detroit, MI 48201, USA; \\ irfana.muqbil@wayne.edu (I.M.); mohammar@karmanos.org (R.M.M.); azmia@karmanos.org (A.S.A.) \\ * Correspondence: philipp@karmanos.org; Tel.: +1-313-575-8746
}

Academic Editors: Takahiro Ochiya and Ryou-u Takahashi

Received: 31 March 2016; Accepted: 13 June 2016; Published: 16 June 2016

\begin{abstract}
Pancreatic ductal adenocarcinoma (PDAC) remains a very challenging malignancy. Disease is diagnosed in an advanced stage in the vast majority of patients, and PDAC cells are often resistant to conventional cytotoxic drugs. Targeted therapies have made no progress in the management of this disease, unlike other cancers. microRNAs (miRs) are small non-coding RNAs that regulate the expression of multitude number of genes by targeting their 3'-UTR mRNA region. Aberrant expression of miRNAs has been linked to the development of various malignancies, including PDAC. In PDAC, a series of miRs have been defined as holding promise for early diagnostics, as indicators of therapy resistance, and even as markers for therapeutic response in patients. In this mini-review, we present an update on the various different miRs that have been defined in PDAC biology.
\end{abstract}

Keywords: pancreatic ductal adenocarcinoma; micro-RNA; biology; diagnosis; therapy; prognosis

\section{Introduction}

Pancreatic cancer is the fourth leading cause of cancer-related deaths in the United States, with 53,070 new cases expected in 2016, of which 41,780 are expected to die from disease [1]. Surgery remains the only potentially curative treatment. However, a majority of patients present with non-resectable disease; only $15 \%-20 \%$ are surgical candidates at the time of diagnosis [2]. Surgery has an overall morbidity and mortality of $24 \%$ and $5.3 \%$, respectively [3]. Tumor size less than $3 \mathrm{~cm}$, negative surgical resection margins, well-differentiated histology and absence of lymph node involvement are favorable prognostic indicators [4]. Following a pancreaticoduodenectomy (Whipple procedure), the five-year survival rate is $25 \%-30 \%$ for node-negative [5] and $10 \%$ for node-positive disease [6]. This can be explained, in part, by the tumor's high resistance to chemotherapy, as well as its propensity to recur and metastasize early, which may be related to the persistence of cancer stem cells (CSCs). Gemcitabine remains a commonly used drug in this disease [7]. Nab-paclitaxel has recently been shown to add to the benefit of gemcitabine in patients with favorable performance status [8]. The combination of fluorouracil, leucovorin, irinotecan, and oxalipatin (FOLFIRINOX) was also shown to be superior to gemcitabine, but, due to its side effect profile, it is reserved for patients with good performance [9]. More recently, monotherapy with S-1, an oral fluoropyrimidine derivative, demonstrated noninferiority to gemcitabine [10].

In light of the disappointing statistics in the prognosis of pancreatic ductal adenocarcinoma (PDAC), early detection of malignant and premalignant lesions is key. Unfortunately, no effective screening tool has been identified to date [11]. The tumors markers carcinoembryonic antigen (CEA) and carbohydrate antigen 19-9 (CA 19-9) are neither sensitive nor specific for screening but are used to follow known disease if they were initially elevated $[12,13]$. 
microRNAs (miRNA) are small (19-25 nucleotides) non-coding ribonucleic acids (RNAs) that interact with messenger RNA (mRNA) and serve as negative regulators of gene expression $[14,15]$ by binding to imperfect complementary regions in the $3^{\prime}$ untranslated region of the target messenger RNA (mRNAs), inhibiting their translation or leading to their degradation. They have been shown to influence cell differentiation, proliferation, and apoptosis [16]. They represent only $3 \%$ of the human genome, but regulate $20 \%-30 \%$ of the protein coding genes $[17,18]$. They were first described in C. elegans in 1993 [19], and have a tissue-specific expression that is modified in a number of different conditions, including malignancy. They have been profiled in many different malignancies including breast [20], lung [21], and colorectal cancer [22] and differential expression was detected with those malignancies, all of which have made miRNAs promising biomarkers. The aim of this review is to present the evidence on the utility of miRNA in the diagnosis, treatment, and prognosis of PDAC.

\section{2. microRNA in PDAC Biology}

An understanding of the processes that govern the development of PDAC is crucial as it sheds light on potential biomarkers of early diagnosis and rational systemic therapeutic approaches. Multiple mutations in the evolution of PDAC are influenced by miRNAs, which serve as tumor promoters or suppressors by silencing or promoting of downstream pathways [23].

Activating mutations in KRAS are present in more than 90\% of PDAC [24]. miRNA-96, 126, and 217, all of which target KRAS, were found to be downregulated in PDAC compared to other noncancerous, as well as normal, pancreatic tissues [25-27]. Furthermore, re-expression of miR-96 and 217 suppressed KRAS activity and resulted in reduced tumor migration and invasion, suggesting their role as tumor suppressors [26,27]. Additionally, miR-217 overexpression phosphorylated AKT levels, suggesting that miR-217 also influences downstream signaling involving cell survival and proliferation [27]. In another study, Kent et al. showed that RAS-responsive element-binding protein (RREB1) repressed the expression of miR-143/145 by binding to the promoter of the cluster [28]. Interestingly, oncogenic KRAS G12D mutations induce expression of RREB1 in PDAC to check the expression of miR-143/145 cluster. As the miR-143/145 cluster expression targets RREB1 protein to inhibit a feed forward circuit of KRAS signals through RREB1, the KRAS (G12D) mediated overexpression of RREB1 simultaneously represses the miR143/145 cluster expression, resulting in promotion of KRAS mediated signaling. Loss of expression of let-7 family miRNAs was described for the first time by Torrisani et al. [29]. Expression of let-7 suppressed KRAS expression and mitogen-activated protein kinase activation (MAPK), and inhibited cell proliferation but failed to hinder tumor progression [29].

Inactivation of $p 53$ occurs in $50 \%-75 \%$ of PDAC, predominantly through missense mutations in the TP53 tumor suppressor gene [30]. Several studies showed that mutant p53 regulates the transcription of certain miRNAs, and, subsequently, influence the expression of their target genes either by degrading their messenger RNA or by inhibiting their translation [31,32]. miR-15a, a known transcriptional target of $p 53$, was shown to be downregulated in PDAC [33]. The overexpression of miR-15a downregulated WNT3A and FGF7, resulting in reduced proliferation and survival of pancreatic cancer cells [33]. p53 has also been shown to induce the expression of miR-200 and repress that of Zeb1 and Zeb2, both of which are known activators of epithelial to mesenchymal transformation (EMT) [34]. In chemoresistant pancreatic cancer cell lines, miR-200 family was downregulated, suggesting a deregulated p53 signaling in those cell lines [34]. Furthermore, upregulation of Zeb1 was associated with downregulation of the miR-200 family expression [35]. The overexpression of miR-200 family led to the downregulation of Jag1, a target of Zeb1 and a ligand of the Notch pathway [35]. p53 not only regulates the expression of certain miRs but also is in turn modulated by specific miRs. miR-491-5p inhibited the expression of both TP53 and Bcl-XL genes, as well as mitogenic signaling pathways, such as STAT3 and PI-3K/Akt, resulting in decreased cell proliferation and induction of apoptosis [36]. Furthermore, Neault showed that miR-137 targets KMD4A messenger RNA during Ras-induced senescence, a tumor suppressor response, and activates both $\mathrm{p} 53$ and retinoblastoma tumor suppressor pathways [37]. miR-137 levels 
were found to be significantly reduced in PDAC; restoring its expression inhibited proliferation and promoted senescence of pancreatic cancer cells [37].

Aberrations in the expression of the $p 16$ genes have been described in PDAC [38]. Also known as cyclin dependent kinase inhibitor 2A, p16 functions as a tumor suppressor gene by regulating cell cycle and cellular senescence. Studies have shown the inhibitory role of miR-10b and -24 on the expression of p16 in malignancies other than pancreatic cancer $[39,40]$. Both miR-10 and -24 were overexpressed in pancreatic cancer [41,42].

The TGF $\beta /$ SMAD pathway has been implicated in EMT. Through binding with their receptors, transforming growth factor $\beta$ (TGF $\beta$ ) isoforms transduce the phosphorylation of SMAD2 and SMAD3, which in turn bind to SMAD4 and translocate to the nucleus, where they regulate the transcription of target genes [43]. Other SMADs include SMAD-1, SMAD-5, and SMAD-8, and are collectively referred to as R-SMAD. On the other hand, SMAD-6 and SMAD-7 are negative regulators of R-SMADs and referred to as I-SMADs, or inhibitory SMADs [44]. While TGF $\beta$ acts as a tumor suppressant in normal cells by inhibiting cell growth, in cancer cells, the TGF $\beta$ /SMAD axis is modified resulting in impaired mediation of growth arrest [45]. Overexpression of the messenger RNAs encoding for TGF $\beta$ was observed PDAC and was associated with poor prognosis [46]. There is evidence suggesting that various microRNAs are regulated by the TGF $\beta /$ SMAD pathway, while others serve as regulators of that same pathway. The 130a/301a/454 microRNA family regulates TGF $\beta$ signaling through suppressing SMAD-4 expression by directly binding to its 3'UTR sequence [47]. This cluster was found to be upregulated in PDAC [48]. In another study, miR-421 and -483-3p promoted PDAC progression through directly regulating the tumor suppressor DPC4/SMAD4 [49,50]. Furthermore, aberrant expression of miR-146a on dendritic cells from PDAC patients was observed, and repression of SMAD-4 resulted in impaired differentiation as well as inhibition of antigen presenting function of dendritic cells, suggesting a role of microRNAs in modulating the immune response in PDAC patients through regulating TGF $\beta /$ SMAD signaling [51]. Overexpression of miR-192 was associated with a reduction in the expression of SMAD-interacting protein 1 (SIP1) [52]. Through direct suppression of SMAD2 and SMAD3, miR-323-3p inhibited TGF $\beta$ signaling, resulting in decreased cell motility and metastasis [53].

\section{3. microRNA in PDAC Diagnosis}

Accumulating evidence is showing that miRNA profiles are cell-specific and tumor-specific [54,55]. miRNAs have been so far isolated from the pancreatic tissue, pancreatic juices, bile, stool, blood, plasma, and sera of patients with pancreatic cancer [56]. Circulating miRNAs, specifically, have several exceptionally appealing characteristics: they are abundant, they are strongly resistant to degradation or modification compared to protein or carbohydrate-based tumor markers, their isolation is non-invasive and their amplification is technically easy and inexpensive [57,58]. Several miRNA profiles were observed to discriminate pancreatic cancer from benign pancreatic pathology and healthy samples. Circulating miRNA-483-3p levels are overexpressed in PDAC compared to intrapapillary mucinous neoplasms and healthy controls, and plasma levels of miR-483-3p differentiated PDAC from intraductal papillary mucinous neoplasm (IPMN) with a sensitivity (Sn) of $43.8 \%$, similar to that of CA19-9 (45\%) [59]. Elevated serum miR-200a and -200b levels were associated with silencing of SIP1 and overexpression of E-cadherin in patients with pancreatic cancer and chronic pancreatitis compared to healthy controls [60]. Serum miR-200a and -200b distinguished patients with PDAC from healthy controls with a Sn and specificity (Sp) of $84.4 \%$ and $87.5 \%$ for miR-200a and $71.1 \%$ and $96.9 \%$ for miR-200b, respectively [60].

Compared to traditionally used markers, serum miR-1290 distinguished patients with low-stage pancreatic cancer from controls better than CA19-9 did, and it was also found to influence pancreatic cancer cell invasion capability [61]. miR-16 and -196a independently discriminated pancreatic cancer patients from those with chronic pancreatitis or healthy controls. When CA 19-9 was added to the analysis, the discrimination was more sensitive and specific compared to microRNA panel or CA19-9 
alone, with a Sn of $92 \%$ and Sp $95.6 \%$ for the discrimination of pancreatic cancer from healthy controls, and $88.4 \%$ and $96.3 \%$ for discriminating pancreatic cancer from chronic pancreatitis [62].

Specific alterations in miRNA expression are also noted in metastatic disease. Singh et al. showed at least a two-fold downregulation of miRNA-205 compared to nonmetastatic disease [63]. On the other hand, miR-146a was upregulated. Diagnostic kits profiling differentially expressed miRNAs were investigated to distinguish benign, premalignant, and malignant pancreatic lesions [64]. Szafranska et al. developed the first miR diagnostic, miRInform Pancreas, which utilized miR-196a and -217 to differentiate chronic pancreatitis from PDAC; their diagnostic Sn and Sp were 95\% [64]. Lee et al. identified a panel of four miRs (miR-21-5p, 485-3p, 708-5p, and 375) that distinguished PDAC from IPMN with a Sn and Sp or $95 \%$ and $85 \%$, respectively [65].

Tables 1 and 2 list miRs that were shown to be upregulated and downregulated, respectively, in patients with pancreatic cancer, compared to benign pancreatic pathology and/or healthy samples.

Table 1. miRNAs upregulated in pancreatic ductal adenocarcinoma (PDAC) compared to benign pancreatic pathology and/or healthy pancreas.

\begin{tabular}{|c|c|c|}
\hline miRNA & Source & Reference \\
\hline miR-10a, miR-10b, miR-146a, miR-204, miR-372 & PDAC tissue & [41] \\
\hline miR-16, miR-21, miR-155, miR-181a, miR-181b, miR-196a, miR-210 & plasma & [62] \\
\hline $\begin{array}{l}\text { miR-155, miR-181a, miR-181b, miR-181b-1, miR-181c, miR-181d, } \\
\text { miR-21, miR-221 }\end{array}$ & PDAC tissue & [66] \\
\hline miR-196a, miR-196b, miR-203, miR-210, miR-222 & PDAC tissue & [67] \\
\hline miR-196a, miR-155, miR-143, miR-145, miR-223, miR-31 & PDAC tissue & [68] \\
\hline $\begin{array}{l}\text { miR-196a, miR-221, miR-222, miR-15b, miR-95, miR-186, miR-190, } \\
\text { miR-200b }\end{array}$ & PDAC tissue & [69] \\
\hline miR-221, miR-181a, miR-181c, miR-155, miR-21, miR-100 & PDAC tissue & [70] \\
\hline miR-132, miR-212 & PDAC tissue & [71] \\
\hline $\begin{array}{l}\text { miR-223, miR-143, miR-27a, miR-21, let-7i, miR-145, miR-142-5p, } \\
\text { miR-142-3p, miR-10a, miR-150, miR-214, miR-107, miR-146b, miR-100, } \\
\text { miR-23a, miR-199a-5p, miR-222, miR-155, miR-103, miR-221, miR34a, } \\
\text { miR130a, miR-331-3p, miR-24, miR-505 }\end{array}$ & PDAC tissue & [72] \\
\hline $\begin{array}{l}\text { miR-107, miR-103, miR-23a, miR-1207-5p, miR-125a-5p, miR-140-5p, } \\
\text { miR-221, miR-143, miR-146, let-7, let-7d, let-7e, miR-145, miR-199b-3p, } \\
\text { miR-199a-3p, miR-138-1, miR-92b, miR-181, miR-1246, miR-31, miR-155, } \\
\text { miR-26a, miR-17, miR-23b, miR-24, miR-500, miR-331-3p, miR-939 }\end{array}$ & PDAC tissue & [73] \\
\hline miR-196a, miR-200a, miR-21, miR-27a, miR-146a & PDAC tissue & [74] \\
\hline miR-155, miR-203, miR-210, miR-222 & PDAC tissue & [75] \\
\hline miR-21, miR-221, miR-100, miR-155, miR-181b, miR-196a & PDAC tissue & [76] \\
\hline miR-21, miR-210, miR-221, miR-222, miR-155 & PDAC tissue & [77] \\
\hline miR-21, miR-196a & PDAC tissue & [78] \\
\hline miR-21, miR-155 & pancreatic juice & [79] \\
\hline miR-205, miR-210, miR-492, miR-1247 & pancreatic juice & [80] \\
\hline $\begin{array}{l}\text { miR-26b, miR-34a, miR-122, miR-126, miR-145, miR-150, miR-223, } \\
\text { miR-505, miR-636, miR-885-5p }\end{array}$ & whole blood & [81] \\
\hline miR-483-3p, miR-21 & plasma & [59] \\
\hline miR-21, 210, 155, 196a & plasma & [82] \\
\hline miR-21 & plasma & [83] \\
\hline miR-210 & plasma & [84] \\
\hline miR-100a, miR-10 & plasma & [85] \\
\hline miR-18a & plasma & [86] \\
\hline miR-182 & plasma & [87] \\
\hline $\begin{array}{l}\text { miR-10b, miR-30c, miR-106b, miR-132, miR-155, miR-181a, miR-181b, } \\
\text { miR-196a, miR-212 }\end{array}$ & plasma & [88] \\
\hline miR-642b, miR-885-5p, miR-22 & plasma & [89] \\
\hline $\mathrm{miR}-221$ & plasma & [90] \\
\hline miR-200a, 200b & serum & {$[60]$} \\
\hline $\begin{array}{l}\text { miR-24, miR-134, miR-146a, miR-378, miR-484, miR-628-3p, miR-1290, } \\
\text { miR-1825 }\end{array}$ & serum & {$[61]$} \\
\hline
\end{tabular}


Table 1. Cont.

\begin{tabular}{lcc}
\hline \multicolumn{1}{c}{ miRNA } & Source & Reference \\
\hline miR-6826-5p, mi-6757-5p, miR-miR-3131, miR-1343-3p, & serum & {$[91]$} \\
miR-20a, miR-21, miR-24, miR-25, miR-99a, miR-185, miR-191 & serum & {$[92]$} \\
miR-10b, miR-30c, miR-106b, miR-155, miR-181a, miR-196a, miR-212 & bile & {$[88]$} \\
miR-21, miR-155 & stool & {$[93]$} \\
\hline
\end{tabular}

Table 2. miRNAs downregulated in PDAC compared to benign pancreatic pathology and/or healthy pancreas.

\begin{tabular}{lcc}
\hline \multicolumn{1}{c}{ miRNA } & Source & Reference \\
\hline miR-148a, miR-148b, miR-375 & PDAC tissue & {$[66]$} \\
miR-216, miR-217, miR-375 & PDAC tissue & {$[67]$} \\
miR-96, miR-130b, miR-148a, miR-217, miR-375 & PDAC tissue & {$[68]$} \\
miR-375 & PDAC tissue & {$[69]$} \\
miR-30d, miR-381, miR-29c, miR-30a, miR-874, miR-324-3p, miR-33b, & & \\
miR-30c-1, miR-139-3p, miR-887, miR-141, miR-575, miR-28-3p, & PDAC tissue & {$[72]$} \\
miR-665, miR-494, miR-617, miR-564, miR-217, miR-130b, miR-148a, & & \\
miR-708, miR-648, miR-148b, miR-345, miR216a & & {$[73]$} \\
miR-1254, miR-559, miR-1274a, let-7f-1 & PDAC tissue \\
miR-217, miR-20a, miR-96 & PDAC tissue & {$[74]$} \\
miR-216, miR-217 & PDAC tissue & {$[75]$} \\
miR-31, miR-122, miR-145, miR-146a & PDAC tissue & {$[77]$} \\
miR-148a, miR-217 & PDAC tissue & {$[78]$} \\
let-7d, miR-146a & plasma & {$[83]$} \\
miR-375 & plasma & {$[90]$} \\
miR-6075, miR-4294, miR-6880-5p, miR-6799-5p, miR-125a-3p, & serum & {$[91]$} \\
miR-4530, miR-6836-3p, miR-4634, miR-7114-5p, miR-4476 & serum & {$[94]$} \\
miR-492, miR-663a & stool & {$[93]$} \\
miR-216 & & \\
\hline
\end{tabular}

\section{4. microRNA in Therapy}

\subsection{Role of miRNAs in PDAC Therapy Resistance}

The poor prognosis of pancreatic cancer is in part attributed to the high resistance rates to conventional chemotherapy. Accumulating evidence shows that most solid tumors are composed of two portions: the bulk and the cancer stem cell population. The latter survive the initial chemotherapy and utilize their self-renewal capabilities to regenerate a secondary population of tumor cells that is resistance to therapy. This inherent characteristic of CSCs might be controlled by specific miRNAs [63]. Jung et al. detected differentially expressed miRNAs in CSCs, including miR-99a, miR-100, miR-125b, miR-192, and miR-429 [95]. Certain alterations in miRNA expression are associated with chemoresistance. miRNA-200 family expression downregulation was observed in gemcitabine-resistant pancreatic cancer cells [96]. The mechanisms through which miRNAs induce chemoresistance have been elucidated in some studies. Hamada et al. showed that miR-365 induced chemoresistance through directly targeting the adaptor protein Src Homology 2 Domain Containing 1 (SHC1) and apoptosis-promoting protein BAX. It also upregulated S100P and Inhibitor of DNA binding 2, both of which are cancer-promoting molecules [97]. On the other hand, miRNA-34 regulated Notch signaling, leading to reduction in pancreatic CSC population [97]. Another study showed that miR-1246 expression induced chemoresistance through downregulating CCNG2 [98].

\subsection{Potential of miRNAs as PDAC Therapeutics}

As miRNAs regulate multiple gene expressions and signaling pathways, miRNA-based therapies are at an advantage over single-gene therapy, and, at least hypothetically, targeting miRNAs is expected 
to produce more effective anti-cancer activities. To that goal, multiple approaches have been utilized in vitro and in vivo, aiming for the downregulation of oncogenic miRNAs and/or the restoration of tumor suppressor ones. Approaches included introducing a miR antagonist or use of an miR mimic agent [55]. Transfecting pancreatic CSCs with a miR-200c mimic decreased colony formation, invasion and chemoresistance of pancreatic CSCs by regulating EMT [99]. Lu et al. reached similar results with transfection of miR-200a [100]. On the same note, transfecting gemcitabine-resistant pancreatic cells with miRNA-205 and miR-7 reduced the expression of TUBB3 and Pak-1, respectively, and reduced the CSC population [63]. Administering complexed micelles of gemcitabine and the tumor suppressor miRNA-205 achieved significant inhibition of tumor growth in a pancreatic tumor model; immuno-histochemical analysis showed decreased tumor cell proliferation and increased apoptosis [101]. Transfection efficiency was $>90 \%$. In another study, targeting miR-21 with lentiviral vectors inhibited cell proliferation [102]. Pancreatic stellate cells (PSCs) represent the precursor cells for cancer-associated fibroblasts in pancreatic tumor stroma [103]. Kuninty et al. showed that suppressing miR-199a and -214 in PSCs abolished the PSC-driven pro-tumor effects and resulted in decreased tumor cell growth [103].

Using treatment with the demethylating agent 5-Aza-2'-deoxycytidine (5-Aza-dC) and HDAC inhibitor vorinostat (SAHA), Nalls et al. restored the expression of miR-34, a transcriptional target of p53, which induced apoptosis and inhibited cell cycle progression and epithelial to mesenchymal transition [104]. Systemic intravenous delivery with miR-34a and miR-143/145 nanovectors inhibited the growth of MiaPsCa-2 subcutaneous xenografts in mouse models; this was displayed even in the orthotopic setting [105]. Treatment with a synthetic (fluorinated) curcumin analogue, CDF, led to the downregulation of miR-21, restoration of miR-200 and tumor suppressor PTEN, and the killing of the CSC population, resulting in suppressed tumor growth [106]. This was previously observed in the work of Ali et al., as well as others [96,107-111]. Oral curcumin was well tolerated and showed some response in one phase II trial [112]. In another study, treatment with isoflavone or 3,3'-diindolylmethane (DIM) reversed the EMT, restored expression of the miRNA-200 family, and resensitized pancreatic cancer cells to gemcitabine [113].

Following miR expression patterns over the course of treatment provides a tool to monitor tumor burden, as well as the emergence of resistant strains of cancer cells, which would prompt modifying therapy [114]. In two studies, plasma levels of miR-18a and 221 dropped postoperatively in nine and eight patients, respectively $[86,90]$; furthermore, in one patient who had recurrence after surgery, miR-18a levels re-elevated with no similar change in the levels of CA19-9.

\section{5. microRNAs as Prognostic Biomarkers}

Evidence shows that certain miR profiles are associated with a more aggressive disease and worse survival. In a meta-analysis involving 1525 patients, overall and disease-free survivals were significantly shorter in patients with high tumoral miR-21 [115]. This was further shown in the work of Abue et al. [59]. Poor survival was also linked to high miR-155, 203, 222, and 10b, and low miR-34a levels [115]. Similarly, lower expression of miR-183 reduced survival compared to higher levels, and was significantly associated with tumor grade, metastasis, and TNM stage [116]. Overexpression of miR-1290 was also associated with worse outcomes [61].

\section{Other Noncoding RNAs}

Although miRNAs have gained a lot of praise as future biomarkers for PDAC, other less popular small noncoding RNAs (snRNAs), as well as long noncoding RNAs (lnRNAs), are also being studied as diagnostic and prognostic biomarkers. Circulating U2 snRNA identified PDAC from controls with high sensitivity and specificity [117]. Overexpression of lncRNAs HOTAIR, HULC, MALAT1, and PVT1 were observed in PDAC compared to non-cancerous controls, and was associated with more aggressive disease [118-121]. In another study, overexpression of lncRNA was associated with inhibition of cell proliferation [122]. 


\section{Conclusions}

Accumulating evidence supports the strong involvement of microRNAs in the pathogenesis of PDAC, highlighting their many different roles in the KRAS, p53, and TGF $\beta$ /SMAD pathways, among others. Whether it is their abundance, their resistance to degradation, the feasibility of isolating them noninvasively, or the ease of amplifying them, miRNAs represent appealing biomarkers that have so far been linked to the diagnosis, therapy, as well as the prognosis of PDAC. However, despite the many efforts that have occurred, a practical application to be used in the clinic is still lacking.

Acknowledgments: Work in the lab of A.S.A. is supported by NIH NCI 1R21CA188818-01A1. The authors acknowledge the support from Perri Foundation and SKY foundation.

Author Contributions: All authors are aware of the content of this manuscript. Maria Diab wrote significant portions of the text and all co-authors have read and edited the manuscript.

Conflicts of Interest: None of the authors have any conflicts of interest to disclose. This manuscript received no sources of funding.

\section{References}

1. Siegel, R.L.; Miller, K.D.; Jemal, A. Cancer statistics, 2016. CA: Cancer J. Clin. 2016, 66, 7-30. [CrossRef] [PubMed]

2. Yeo, C.J.; Cameron, J.L. Prognostic factors in ductal pancreatic cancer. Langenbeck's Arch. Surg. Deutsche Ges. Chir. 1998, 383, 129-133. [CrossRef]

3. Benassai, G.; Mastrorilli, M.; Quarto, G.; Cappiello, A.; Giani, U.; Mosella, G. Survival after pancreaticoduodenectomy for ductal adenocarcinoma of the head of the pancreas. Chir. Ital. 2000, 52, 263-270. [PubMed]

4. Yeo, C.J.; Cameron, J.L.; Sohn, T.A.; Lillemoe, K.D.; Pitt, H.A.; Talamini, M.A.; Hruban, R.H.; Ord, S.E.; Sauter, P.K.; Coleman, J.; et al. Six hundred fifty consecutive pancreaticoduodenectomies in the 1990s: Pathology, complications, and outcomes. Ann. Surg. 1997, 226, 248-257, discussion 257-260. [CrossRef] [PubMed]

5. Trede, M.; Schwall, G.; Saeger, H.D. Survival after pancreatoduodenectomy. 118 consecutive resections without an operative mortality. Ann. Surg. 1990, 211, 447-458. [CrossRef] [PubMed]

6. Kang, M.J.; Jang, J.Y.; Chang, Y.R.; Kwon, W.; Jung, W.; Kim, S.W. Revisiting the concept of lymph node metastases of pancreatic head cancer: Number of metastatic lymph nodes and lymph node ratio according to n stage. Ann. Surg. Oncol. 2014, 21, 1545-1551. [CrossRef] [PubMed]

7. Heinemann, V.; Haas, M.; Boeck, S. Systemic treatment of advanced pancreatic cancer. Cancer Treat. Rev. 2012, 38, 843-853. [CrossRef] [PubMed]

8. Von Hoff, D.D.; Ervin, T.; Arena, F.P.; Chiorean, E.G.; Infante, J.; Moore, M.; Seay, T.; Tjulandin, S.A.; Ma, W.W.; Saleh, M.N.; et al. Increased survival in pancreatic cancer with nab-paclitaxel plus gemcitabine. N. Engl. J. Med. 2013, 369, 1691-1703. [CrossRef] [PubMed]

9. Conroy, T.; Desseigne, F.; Ychou, M.; Bouche, O.; Guimbaud, R.; Becouarn, Y.; Adenis, A.; Raoul, J.L.; Gourgou-Bourgade, S.; de la Fouchardiere, C.; et al. Folfirinox versus gemcitabine for metastatic pancreatic cancer. N. Engl. J. Med. 2011, 364, 1817-1825. [CrossRef] [PubMed]

10. Ueno, H.; Ioka, T.; Ikeda, M.; Ohkawa, S.; Yanagimoto, H.; Boku, N.; Fukutomi, A.; Sugimori, K.; Baba, H.; Yamao, K.; et al. Randomized phase iii study of gemcitabine plus s-1, s-1 alone, or gemcitabine alone in patients with locally advanced and metastatic pancreatic cancer in japan and taiwan: Gest study. J. Clin. Oncol. 2013, 31, 1640-1648. [CrossRef] [PubMed]

11. Ryan, D.P.; Hong, T.S.; Bardeesy, N. Pancreatic adenocarcinoma. N. Engl. J. Med. 2014, 371, 1039-1049. [CrossRef] [PubMed]

12. DiMagno, E.P.; Reber, H.A.; Tempero, M.A. Aga technical review on the epidemiology, diagnosis, and treatment of pancreatic ductal adenocarcinoma. American gastroenterological association. Gastroenterology 1999, 117, 1464-1484. [CrossRef]

13. Lamerz, R. Role of tumour markers, cytogenetics. Ann. Oncol. 1999, 10 (Suppl. 4), 145-149. [CrossRef] [PubMed] 
14. Galasso, M.; Sandhu, S.K.; Volinia, S. MicroRNA expression signatures in solid malignancies. Cancer J. (Sudbury Mass.) 2012, 18, 238-243. [CrossRef] [PubMed]

15. Zhang, B.; Pan, X.; Cobb, G.P.; Anderson, T.A. MicroRNAs as oncogenes and tumor suppressors. Dev. Biol. 2007, 302, 1-12. [CrossRef] [PubMed]

16. Iorio, M.V.; Croce, C.M. MicroRNAs in cancer: Small molecules with a huge impact. J. Clin. Oncol. 2009, 27, 5848-5856. [CrossRef] [PubMed]

17. Bentwich, I.; Avniel, A.; Karov, Y.; Aharonov, R.; Gilad, S.; Barad, O.; Barzilai, A.; Einat, P.; Einav, U.; Meiri, E.; et al. Identification of hundreds of conserved and nonconserved human microRNAs. Nat. Genet. 2005, 37, 766-770. [CrossRef] [PubMed]

18. Carthew, R.W. Gene regulation by microRNAs. Curr. Opin. Genet. Dev. 2006, 16, 203-208. [CrossRef] [PubMed]

19. Lee, R.C.; Feinbaum, R.L.; Ambros, V. The c. Elegans heterochronic gene lin-4 encodes small RNAs with antisense complementarity to lin-14. Cell 1993, 75, 843-854. [CrossRef]

20. Iorio, M.V.; Ferracin, M.; Liu, C.G.; Veronese, A.; Spizzo, R.; Sabbioni, S.; Magri, E.; Pedriali, M.; Fabbri, M.; Campiglio, M.; et al. MicroRNA gene expression deregulation in human breast cancer. Cancer Res. 2005, 65, 7065-7070. [CrossRef] [PubMed]

21. Johnson, S.M.; Grosshans, H.; Shingara, J.; Byrom, M.; Jarvis, R.; Cheng, A.; Labourier, E.; Reinert, K.L.; Brown, D.; Slack, F.J. Ras is regulated by the let-7 microRNA family. Cell 2005, 120, 635-647. [CrossRef] [PubMed]

22. Michael, M.Z.; SM, O.C.; van Holst Pellekaan, N.G.; Young, G.P.; James, R.J. Reduced accumulation of specific microRNAs in colorectal neoplasia. Mol. Cancer Res. MCR 2003, 1, 882-891. [PubMed]

23. Bhardwaj, A.; Arora, S.; Prajapati, V.K.; Singh, S.; Singh, A.P. Cancer "stemness"- regulating microRNAs: Role, mechanisms and therapeutic potential. Curr. Drug Targets 2013, 14, 1175-1184. [CrossRef] [PubMed]

24. Almoguera, C.; Shibata, D.; Forrester, K.; Martin, J.; Arnheim, N.; Perucho, M. Most human carcinomas of the exocrine pancreas contain mutant c-k-ras genes. Cell 1988, 53, 549-554. [CrossRef]

25. Jiao, L.R.; Frampton, A.E.; Jacob, J.; Pellegrino, L.; Krell, J.; Giamas, G.; Tsim, N.; Vlavianos, P.; Cohen, P.; Ahmad, R.; et al. MicroRNAs targeting oncogenes are down-regulated in pancreatic malignant transformation from benign tumors. PLoS ONE 2012, 7, e32068. [CrossRef] [PubMed]

26. Yu, S.; Lu, Z.; Liu, C.; Meng, Y.; Ma, Y.; Zhao, W.; Liu, J.; Yu, J.; Chen, J. MiRNA-96 suppresses kras and functions as a tumor suppressor gene in pancreatic cancer. Cancer Res. 2010, 70, 6015-6025. [CrossRef] [PubMed]

27. Zhao, W.G.; Yu, S.N.; Lu, Z.H.; Ma, Y.H.; Gu, Y.M.; Chen, J. The mir-217 microRNA functions as a potential tumor suppressor in pancreatic ductal adenocarcinoma by targeting kras. Carcinogenesis 2010, 31, 1726-1733. [CrossRef] [PubMed]

28. Kent, O.A.; Chivukula, R.R.; Mullendore, M.; Wentzel, E.A.; Feldmann, G.; Lee, K.H.; Liu, S.; Leach, S.D.; Maitra, A.; Mendell, J.T. Repression of the mir-143/145 cluster by oncogenic ras initiates a tumor-promoting feed-forward pathway. Genes Dev. 2010, 24, 2754-2759. [CrossRef] [PubMed]

29. Torrisani, J.; Bournet, B.; du Rieu, M.C.; Bouisson, M.; Souque, A.; Escourrou, J.; Buscail, L.; Cordelier, P. Let-7 microRNA transfer in pancreatic cancer-derived cells inhibits in vitro cell proliferation but fails to alter tumor progression. Hum. Gene Ther. 2009, 20, 831-844. [CrossRef] [PubMed]

30. Scarpa, A.; Capelli, P.; Mukai, K.; Zamboni, G.; Oda, T.; Iacono, C.; Hirohashi, S. Pancreatic adenocarcinomas frequently show p53 gene mutations. Am. J. Pathol. 1993, 142, 1534-1543. [PubMed]

31. Dong, P.; Karaayvaz, M.; Jia, N.; Kaneuchi, M.; Hamada, J.; Watari, H.; Sudo, S.; Ju, J.; Sakuragi, N. Mutant p53 gain-of-function induces epithelial-mesenchymal transition through modulation of the mir-130b-zeb1 axis. Oncogene 2013, 32, 3286-3295. [CrossRef] [PubMed]

32. Neilsen, P.M.; Noll, J.E.; Mattiske, S.; Bracken, C.P.; Gregory, P.A.; Schulz, R.B.; Lim, S.P.; Kumar, R.; Suetani, R.J.; Goodall, G.J.; et al. Mutant p53 drives invasion in breast tumors through up-regulation of mir-155. Oncogene 2013, 32, 2992-3000. [CrossRef] [PubMed]

33. Zhang, X.J.; Ye, H.; Zeng, C.W.; He, B.; Zhang, H.; Chen, Y.Q. Dysregulation of mir-15a and mir-214 in human pancreatic cancer. J. Hematol. Oncol. 2010, 3, 46. [CrossRef] [PubMed]

34. Soubani, O.; Ali, A.S.; Logna, F.; Ali, S.; Philip, P.A.; Sarkar, F.H. Re-expression of mir-200 by novel approaches regulates the expression of pten and mt1-mmp in pancreatic cancer. Carcinogenesis 2012, 33, 1563-1571. [CrossRef] [PubMed] 
35. Brabletz, S.; Bajdak, K.; Meidhof, S.; Burk, U.; Niedermann, G.; Firat, E.; Wellner, U.; Dimmler, A.; Faller, G.; Schubert, J.; et al. The zeb1/mir-200 feedback loop controls notch signalling in cancer cells. EMBO J. 2011, 30, 770-782. [CrossRef] [PubMed]

36. Guo, R.; Wang, Y.; Shi, W.Y.; Liu, B.; Hou, S.Q.; Liu, L. MicroRNA mir-491-5p targeting both tp53 and bcl-xl induces cell apoptosis in sw1990 pancreatic cancer cells through mitochondria mediated pathway. Molecules (Basel Switzerland) 2012, 17, 14733-14747. [CrossRef] [PubMed]

37. Neault, M.; Mallette, F.A.; Richard, S. Mir-137 modulates a tumor suppressor network-inducing senescence in pancreatic cancer cells. Cell Rep. 2016, 14, 1966-1978. [CrossRef] [PubMed]

38. Okamoto, A.; Demetrick, D.J.; Spillare, E.A.; Hagiwara, K.; Hussain, S.P.; Bennett, W.P.; Forrester, K.; Gerwin, B.; Serrano, M.; Beach, D.H.; et al. Mutations and altered expression of p16ink4 in human cancer. Proc. Natl. Acad. Sci. USA 1994, 91, 11045-11049. [CrossRef] [PubMed]

39. Lal, A.; Kim, H.H.; Abdelmohsen, K.; Kuwano, Y.; Pullmann, R., Jr.; Srikantan, S.; Subrahmanyam, R.; Martindale, J.L.; Yang, X.; Ahmed, F.; et al. P16(ink4a) translation suppressed by mir-24. PLoS ONE 2008, 3, e1864. [CrossRef] [PubMed]

40. Venkataraman, S.; Alimova, I.; Fan, R.; Harris, P.; Foreman, N.; Vibhakar, R. MicroRNA 128a increases intracellular ros level by targeting bmi-1 and inhibits medulloblastoma cancer cell growth by promoting senescence. PLoS ONE 2010, 5, e10748. [CrossRef] [PubMed]

41. Nakata, K.; Ohuchida, K.; Mizumoto, K.; Kayashima, T.; Ikenaga, N.; Sakai, H.; Lin, C.; Fujita, H.; Otsuka, T.; Aishima, S.; et al. MicroRNA-10b is overexpressed in pancreatic cancer, promotes its invasiveness, and correlates with a poor prognosis. Surgery 2011, 150, 916-922. [CrossRef] [PubMed]

42. Zhang, L.; Jamaluddin, M.S.; Weakley, S.M.; Yao, Q.; Chen, C. Roles and mechanisms of microRNAs in pancreatic cancer. World J. Surg. 2011, 35, 1725-1731. [CrossRef] [PubMed]

43. Cano, C.E.; Motoo, Y.; Iovanna, J.L. Epithelial-to-mesenchymal transition in pancreatic adenocarcinoma. Sci. World J. 2010, 10, 1947-1957. [CrossRef] [PubMed]

44. Rachagani, S.; Macha, M.A.; Heimann, N.; Seshacharyulu, P.; Haridas, D.; Chugh, S.; Batra, S.K. Clinical implications of miRNAs in the pathogenesis, diagnosis and therapy of pancreatic cancer. Adv. Drug Deliv. Rev. 2015, 81, 16-33. [CrossRef] [PubMed]

45. Nicolas, F.J.; Hill, C.S. Attenuation of the tgf-beta-smad signaling pathway in pancreatic tumor cells confers resistance to tgf-beta-induced growth arrest. Oncogene 2003, 22, 3698-3711. [CrossRef] [PubMed]

46. Friess, H.; Yamanaka, Y.; Buchler, M.; Ebert, M.; Beger, H.G.; Gold, L.I.; Korc, M. Enhanced expression of transforming growth factor beta isoforms in pancreatic cancer correlates with decreased survival. Gastroenterology 1993, 105, 1846-1856. [CrossRef]

47. Liu, L.; Nie, J.; Chen, L.; Dong, G.; Du, X.; Wu, X.; Tang, Y.; Han, W. The oncogenic role of microRNA-130a/301a/454 in human colorectal cancer via targeting smad4 expression. PLoS ONE 2013,8, e55532. [CrossRef] [PubMed]

48. Chen, Z.; Chen, L.Y.; Dai, H.Y.; Wang, P.; Gao, S.; Wang, K. Mir-301a promotes pancreatic cancer cell proliferation by directly inhibiting bim expression. J. Cell. Biochem. 2012, 113, 3229-3235. [CrossRef] [PubMed]

49. Hao, J.; Zhang, S.; Zhou, Y.; Hu, X.; Shao, C. MicroRNA 483-3p suppresses the expression of dpc4/smad4 in pancreatic cancer. FEBS Lett. 2011, 585, 207-213. [CrossRef] [PubMed]

50. Hao, J.; Zhang, S.; Zhou, Y.; Liu, C.; Hu, X.; Shao, C. MicroRNA 421 suppresses dpc4/smad4 in pancreatic cancer. Biochem. Biophys. Res. Commun. 2011, 406, 552-557. [CrossRef] [PubMed]

51. Du, J.; Wang, J.; Tan, G.; Cai, Z.; Zhang, L.; Tang, B.; Wang, Z. Aberrant elevated microRNA-146a in dendritic cells $(\mathrm{dc})$ induced by human pancreatic cancer cell line bxpc-3-conditioned medium inhibits dc maturation and activation. Med. Oncol. (Northwood Lond. Engl.) 2012, 29, 2814-2823. [CrossRef] [PubMed]

52. Zhao, C.; Zhang, J.; Zhang, S.; Yu, D.; Chen, Y.; Liu, Q.; Shi, M.; Ni, C.; Zhu, M. Diagnostic and biological significance of microRNA-192 in pancreatic ductal adenocarcinoma. Oncol. Rep. 2013, 30, 276-284. [CrossRef] [PubMed]

53. Wang, C.; Liu, P.; Wu, H.; Cui, P.; Li, Y.; Liu, Y.; Liu, Z.; Gou, S. MicroRNA-323-3p inhibits cell invasion and metastasis in pancreatic ductal adenocarcinoma via direct suppression of SMAD2 and SMAD3. Oncotarget 2016, 7, 14912-14924. [PubMed] 
54. Lu, J.; Getz, G.; Miska, E.A.; Alvarez-Saavedra, E.; Lamb, J.; Peck, D.; Sweet-Cordero, A.; Ebert, B.L.; Mak, R.H.; Ferrando, A.A.; et al. MicroRNA expression profiles classify human cancers. Nature 2005, 435, 834-838. [CrossRef] [PubMed]

55. Rosenfeld, N.; Aharonov, R.; Meiri, E.; Rosenwald, S.; Spector, Y.; Zepeniuk, M.; Benjamin, H.; Shabes, N.; Tabak, S.; Levy, A.; et al. MicroRNAs accurately identify cancer tissue origin. Nat. Biotechnol. 2008, 26, 462-469. [CrossRef] [PubMed]

56. Visani, M.; Acquaviva, G.; Fiorino, S.; Bacchi Reggiani, M.L.; Masetti, M.; Franceschi, E.; Fornelli, A.; Jovine, E.; Fabbri, C.; Brandes, A.A.; et al. Contribution of microRNA analysis to characterisation of pancreatic lesions: A review. J. Clinical Pathol. 2015, 68, 859-869. [CrossRef] [PubMed]

57. Kishikawa, T.; Otsuka, M.; Ohno, M.; Yoshikawa, T.; Takata, A.; Koike, K. Circulating RNAs as new biomarkers for detecting pancreatic cancer. World J. Gastroenterol. 2015, 21, 8527-8540. [CrossRef] [PubMed]

58. Schwarzenbach, H.; Nishida, N.; Calin, G.A.; Pantel, K. Clinical relevance of circulating cell-free microRNAs in cancer. Nat. Rev. Clin. Oncol. 2014, 11, 145-156. [CrossRef] [PubMed]

59. Abue, M.; Yokoyama, M.; Shibuya, R.; Tamai, K.; Yamaguchi, K.; Sato, I.; Tanaka, N.; Hamada, S.; Shimosegawa, T.; Sugamura, K.; et al. Circulating mir-483-3p and mir-21 is highly expressed in plasma of pancreatic cancer. Int. J. Oncol. 2015, 46, 539-547. [CrossRef] [PubMed]

60. Li, A.; Omura, N.; Hong, S.M.; Vincent, A.; Walter, K.; Griffith, M.; Borges, M.; Goggins, M. Pancreatic cancers epigenetically silence sip1 and hypomethylate and overexpress mir-200a/200b in association with elevated circulating mir-200a and mir-200b levels. Cancer Res. 2010, 70, 5226-5237. [CrossRef] [PubMed]

61. Li, A.; Yu, J.; Kim, H.; Wolfgang, C.L.; Canto, M.I.; Hruban, R.H.; Goggins, M. MicroRNA array analysis finds elevated serum mir-1290 accurately distinguishes patients with low-stage pancreatic cancer from healthy and disease controls. Clin. Cancer Res. 2013, 19, 3600-3610. [CrossRef] [PubMed]

62. Liu, J.; Gao, J.; Du, Y.; Li, Z.; Ren, Y.; Gu, J.; Wang, X.; Gong, Y.; Wang, W.; Kong, X. Combination of plasma microRNAs with serum ca19-9 for early detection of pancreatic cancer. Int. J. Cancer 2012, 131, 683-691. [CrossRef] [PubMed]

63. Singh, S.; Chitkara, D.; Kumar, V.; Behrman, S.W.; Mahato, R.I. MiRNA profiling in pancreatic cancer and restoration of chemosensitivity. Cancer Lett. 2013, 334, 211-220. [CrossRef] [PubMed]

64. Szafranska-Schwarzbach, A.E.; Adai, A.T.; Lee, L.S.; Conwell, D.L.; Andruss, B.F. Development of a miRNA-based diagnostic assay for pancreatic ductal adenocarcinoma. Expert Rev. Mol. Diagn. 2011, 11, 249-257. [PubMed]

65. Lee, L.S.; Szafranska-Schwarzbach, A.E.; Wylie, D.; Doyle, L.A.; Bellizzi, A.M.; Kadiyala, V.; Suleiman, S.; Banks, P.A.; Andruss, B.F.; Conwell, D.L. Investigating microRNA expression profiles in pancreatic cystic neoplasms. Clin. Transl. Gastroenterol. 2014, 5, e47. [CrossRef] [PubMed]

66. Bloomston, M.; Frankel, W.L.; Petrocca, F.; Volinia, S.; Alder, H.; Hagan, J.P.; Liu, C.G.; Bhatt, D.; Taccioli, C.; Croce, C.M. MicroRNA expression patterns to differentiate pancreatic adenocarcinoma from normal pancreas and chronic pancreatitis. Jama 2007, 297, 1901-1908. [CrossRef] [PubMed]

67. Szafranska, A.E.; Davison, T.S.; John, J.; Cannon, T.; Sipos, B.; Maghnouj, A.; Labourier, E.; Hahn, S.A. MicroRNA expression alterations are linked to tumorigenesis and non-neoplastic processes in pancreatic ductal adenocarcinoma. Oncogene 2007, 26, 4442-4452. [CrossRef] [PubMed]

68. Szafranska, A.E.; Doleshal, M.; Edmunds, H.S.; Gordon, S.; Luttges, J.; Munding, J.B.; Barth, R.J., Jr.; Gutmann, E.J.; Suriawinata, A.A.; Marc Pipas, J.; et al. Analysis of microRNAs in pancreatic fine-needle aspirates can classify benign and malignant tissues. Clin. Chem. 2008, 54, 1716-1724. [CrossRef] [PubMed]

69. Zhang, Y.; Li, M.; Wang, H.; Fisher, W.E.; Lin, P.H.; Yao, Q.; Chen, C. Profiling of 95 microRNAs in pancreatic cancer cell lines and surgical specimens by real-time pcr analysis. World J. Surg. 2009, 33, 698-709. [CrossRef] [PubMed]

70. Lee, E.J.; Gusev, Y.; Jiang, J.; Nuovo, G.J.; Lerner, M.R.; Frankel, W.L.; Morgan, D.L.; Postier, R.G.; Brackett, D.J.; Schmittgen, T.D. Expression profiling identifies microRNA signature in pancreatic cancer. Int. J. Cancer 2007, 120, 1046-1054. [CrossRef] [PubMed]

71. Park, J.K.; Henry, J.C.; Jiang, J.; Esau, C.; Gusev, Y.; Lerner, M.R.; Postier, R.G.; Brackett, D.J.; Schmittgen, T.D. Mir-132 and mir-212 are increased in pancreatic cancer and target the retinoblastoma tumor suppressor. Biochem. Biophys. Res. Commun. 2011, 406, 518-523. [CrossRef] [PubMed] 
72. Jamieson, N.B.; Morran, D.C.; Morton, J.P.; Ali, A.; Dickson, E.J.; Carter, C.R.; Sansom, O.J.; Evans, T.R.; McKay, C.J.; Oien, K.A. MicroRNA molecular profiles associated with diagnosis, clinicopathologic criteria, and overall survival in patients with resectable pancreatic ductal adenocarcinoma. Clin. Cancer Res. 2012, 18, 534-545. [CrossRef] [PubMed]

73. Piepoli, A.; Tavano, F.; Copetti, M.; Mazza, T.; Palumbo, O.; Panza, A.; di Mola, F.F.; Pazienza, V.; Mazzoccoli, G.; Biscaglia, G.; et al. MiRNA expression profiles identify drivers in colorectal and pancreatic cancers. PLoS ONE 2012, 7, e33663. [CrossRef] [PubMed]

74. Hong, T.H.; Park, I.Y. MicroRNA expression profiling of diagnostic needle aspirates from surgical pancreatic cancer specimens. Ann. Surg. Treat. Res. 2014, 87, 290-297. [CrossRef] [PubMed]

75. Greither, T.; Grochola, L.F.; Udelnow, A.; Lautenschlager, C.; Wurl, P.; Taubert, H. Elevated expression of microRNAs 155, 203, 210 and 222 in pancreatic tumors is associated with poorer survival. Int. J. Cancer 2010, 126, 73-80. [CrossRef] [PubMed]

76. Panarelli, N.C.; Chen, Y.T.; Zhou, X.K.; Kitabayashi, N.; Yantiss, R.K. MicroRNA expression aids the preoperative diagnosis of pancreatic ductal adenocarcinoma. Pancreas 2012, 41, 685-690. [CrossRef] [PubMed]

77. Papaconstantinou, I.G.; Manta, A.; Gazouli, M.; Lyberopoulou, A.; Lykoudis, P.M.; Polymeneas, G.; Voros, D. Expression of microRNAs in patients with pancreatic cancer and its prognostic significance. Pancreas 2013, 42, 67-71. [CrossRef] [PubMed]

78. Xue, Y.; Abou Tayoun, A.N.; Abo, K.M.; Pipas, J.M.; Gordon, S.R.; Gardner, T.B.; Barth, R.J., Jr.; Suriawinata, A.A.; Tsongalis, G.J. MicroRNAs as diagnostic markers for pancreatic ductal adenocarcinoma and its precursor, pancreatic intraepithelial neoplasm. Cancer Genet. 2013, 206, 217-221. [CrossRef] [PubMed]

79. Sadakari, Y.; Ohtsuka, T.; Ohuchida, K.; Tsutsumi, K.; Takahata, S.; Nakamura, M.; Mizumoto, K.; Tanaka, M. MicroRNA expression analyses in preoperative pancreatic juice samples of pancreatic ductal adenocarcinoma. JOP 2010, 11, 587-592. [PubMed]

80. Wang, J.; Raimondo, M.; Guha, S.; Chen, J.; Diao, L.; Dong, X.; Wallace, M.B.; Killary, A.M.; Frazier, M.L.; Woodward, T.A.; et al. Circulating microRNAs in pancreatic juice as candidate biomarkers of pancreatic cancer. J. Cancer 2014, 5, 696-705. [CrossRef] [PubMed]

81. Schultz, N.A.; Dehlendorff, C.; Jensen, B.V.; Bjerregaard, J.K.; Nielsen, K.R.; Bojesen, S.E.; Calatayud, D.; Nielsen, S.E.; Yilmaz, M.; Hollander, N.H.; et al. MicroRNA biomarkers in whole blood for detection of pancreatic cancer. Jama 2014, 311, 392-404. [CrossRef] [PubMed]

82. Wang, J.; Chen, J.; Chang, P.; LeBlanc, A.; Li, D.; Abbruzzesse, J.L.; Frazier, M.L.; Killary, A.M.; Sen, S. MicroRNAs in plasma of pancreatic ductal adenocarcinoma patients as novel blood-based biomarkers of disease. Cancer Prev. Res. (Philadelphia Pa.) 2009, 2, 807-813. [CrossRef] [PubMed]

83. Ali, S.; Almhanna, K.; Chen, W.; Philip, P.A.; Sarkar, F.H. Differentially expressed miRNAs in the plasma may provide a molecular signature for aggressive pancreatic cancer. Am. J. Transl. Res. 2010, 3, 28-47. [PubMed]

84. Ho, A.S.; Huang, X.; Cao, H.; Christman-Skieller, C.; Bennewith, K.; Le, Q.T.; Koong, A.C. Circulating mir-210 as a novel hypoxia marker in pancreatic cancer. Transl. Oncol. 2010, 3, 109-113. [CrossRef] [PubMed]

85. LaConti, J.J.; Shivapurkar, N.; Preet, A.; Deslattes Mays, A.; Peran, I.; Kim, S.E.; Marshall, J.L.; Riegel, A.T.; Wellstein, A. Tissue and serum microRNAs in the kras(g12d) transgenic animal model and in patients with pancreatic cancer. PLoS ONE 2011, 6, e20687. [CrossRef] [PubMed]

86. Morimura, R.; Komatsu, S.; Ichikawa, D.; Takeshita, H.; Tsujiura, M.; Nagata, H.; Konishi, H.; Shiozaki, A.; Ikoma, H.; Okamoto, K.; et al. Novel diagnostic value of circulating mir-18a in plasma of patients with pancreatic cancer. Br. J. Cancer 2011, 105, 1733-1740. [CrossRef] [PubMed]

87. Chen, Q.; Yang, L.; Xiao, Y.; Zhu, J.; Li, Z. Circulating microRNA-182 in plasma and its potential diagnostic and prognostic value for pancreatic cancer. Med. Oncol. (Northwood Lond. Engl.) 2014, 31, 225. [CrossRef] [PubMed]

88. Cote, G.A.; Gore, A.J.; McElyea, S.D.; Heathers, L.E.; Xu, H.; Sherman, S.; Korc, M. A pilot study to develop a diagnostic test for pancreatic ductal adenocarcinoma based on differential expression of select miRNA in plasma and bile. Am. J. Gastroenterol. 2014, 109, 1942-1952. [CrossRef] [PubMed]

89. Ganepola, G.A.; Rutledge, J.R.; Suman, P.; Yiengpruksawan, A.; Chang, D.H. Novel blood-based microRNA biomarker panel for early diagnosis of pancreatic cancer. World J. Gastrointest. Oncol. 2014, 6, $22-33$. [CrossRef] [PubMed] 
90. Kawaguchi, T.; Komatsu, S.; Ichikawa, D.; Morimura, R.; Tsujiura, M.; Konishi, H.; Takeshita, H.; Nagata, H.; Arita, T.; Hirajima, S.; et al. Clinical impact of circulating mir-221 in plasma of patients with pancreatic cancer. Br. J. Cancer 2013, 108, 361-369. [CrossRef] [PubMed]

91. Kojima, M.; Sudo, H.; Kawauchi, J.; Takizawa, S.; Kondou, S.; Nobumasa, H.; Ochiai, A. MicroRNA markers for the diagnosis of pancreatic and biliary-tract cancers. PLoS ONE 2015, 10, e0118220. [CrossRef] [PubMed]

92. Liu, R.; Chen, X.; Du, Y.; Yao, W.; Shen, L.; Wang, C.; Hu, Z.; Zhuang, R.; Ning, G.; Zhang, C.; et al. Serum microRNA expression profile as a biomarker in the diagnosis and prognosis of pancreatic cancer. Clin. Chem. 2012, 58, 610-618. [CrossRef] [PubMed]

93. Yang, J.Y.; Sun, Y.W.; Liu, D.J.; Zhang, J.F.; Li, J.; Hua, R. MicroRNAs in stool samples as potential screening biomarkers for pancreatic ductal adenocarcinoma cancer. Am. J. Cancer Res. 2014, 4, 663-673. [PubMed]

94. Lin, M.S.; Chen, W.C.; Huang, J.X.; Gao, H.J.; Sheng, H.H. Aberrant expression of microRNAs in serum may identify individuals with pancreatic cancer. Int. J. Clin. Exp. Med. 2014, 7, 5226-5234. [PubMed]

95. Jung, D.E.; Wen, J.; Oh, T.; Song, S.Y. Differentially expressed microRNAs in pancreatic cancer stem cells. Pancreas 2011, 40, 1180-1187. [CrossRef] [PubMed]

96. Park, J.K.; Lee, E.J.; Esau, C.; Schmittgen, T.D. Antisense inhibition of microRNA-21 or -221 arrests cell cycle, induces apoptosis, and sensitizes the effects of gemcitabine in pancreatic adenocarcinoma. Pancreas 2009, 38, e190-e199. [CrossRef] [PubMed]

97. Ji, Q.; Hao, X.; Zhang, M.; Tang, W.; Yang, M.; Li, L.; Xiang, D.; Desano, J.T.; Bommer, G.T.; Fan, D.; et al. MicroRNA mir-34 inhibits human pancreatic cancer tumor-initiating cells. PLoS ONE 2009, 4, e6816. [CrossRef] [PubMed]

98. Hasegawa, S.; Eguchi, H.; Nagano, H.; Konno, M.; Tomimaru, Y.; Wada, H.; Hama, N.; Kawamoto, K.; Kobayashi, S.; Nishida, N.; et al. MicroRNA-1246 expression associated with cong2-mediated chemoresistance and stemness in pancreatic cancer. Br. J. Cancer 2014, 111, 1572-1580. [CrossRef] [PubMed]

99. Ma, C.; Huang, T.; Ding, Y.C.; Yu, W.; Wang, Q.; Meng, B.; Luo, S.X. MicroRNA-200c overexpression inhibits chemoresistance, invasion and colony formation of human pancreatic cancer stem cells. Int. J. Clin. Exp. Pathol. 2015, 8, 6533-6539. [PubMed]

100. Lu, Y.; Lu, J.; Li, X.; Zhu, H.; Fan, X.; Zhu, S.; Wang, Y.; Guo, Q.; Wang, L.; Huang, Y.; et al. Mir-200a inhibits epithelial-mesenchymal transition of pancreatic cancer stem cell. BMC Cancer 2014, 14, 85. [CrossRef] [PubMed]

101. Mittal, A.; Chitkara, D.; Behrman, S.W.; Mahato, R.I. Efficacy of gemcitabine conjugated and miRNA-205 complexed micelles for treatment of advanced pancreatic cancer. Biomaterials 2014, 35, 7077-7087. [CrossRef] [PubMed]

102. Sicard, F.; Gayral, M.; Lulka, H.; Buscail, L.; Cordelier, P. Targeting mir-21 for the therapy of pancreatic cancer. Mol. Ther. 2013, 21, 986-994. [CrossRef] [PubMed]

103. Kuninty, P.R.; Bojmar, L.; Tjomsland, V.; Larsson, M.; Storm, G.; Ostman, A.; Sandstrom, P.; Prakash, J. MicroRNA-199a and -214 as potential therapeutic targets in pancreatic stellate cells in pancreatic tumor. Oncotarget 2016, 7, 1949-2553. [CrossRef] [PubMed]

104. Nalls, D.; Tang, S.N.; Rodova, M.; Srivastava, R.K.; Shankar, S. Targeting epigenetic regulation of mir-34a for treatment of pancreatic cancer by inhibition of pancreatic cancer stem cells. PLoS ONE 2011, 6, e24099. [CrossRef] [PubMed]

105. Pramanik, D.; Campbell, N.R.; Karikari, C.; Chivukula, R.; Kent, O.A.; Mendell, J.T.; Maitra, A. Restitution of tumor suppressor microRNAs using a systemic nanovector inhibits pancreatic cancer growth in mice. Mol. Cancer Ther. 2011, 10, 1470-1480. [CrossRef] [PubMed]

106. Bao, B.; Ali, S.; Kong, D.; Sarkar, S.H.; Wang, Z.; Banerjee, S.; Aboukameel, A.; Padhye, S.; Philip, P.A.; Sarkar, F.H. Anti-tumor activity of a novel compound-cdf is mediated by regulating mir-21, mir-200, and pten in pancreatic cancer. PLoS ONE 2011, 6, e17850. [CrossRef] [PubMed]

107. Ali, S.; Ahmad, A.; Banerjee, S.; Padhye, S.; Dominiak, K.; Schaffert, J.M.; Wang, Z.; Philip, P.A.; Sarkar, F.H. Gemcitabine sensitivity can be induced in pancreatic cancer cells through modulation of mir-200 and mir-21 expression by curcumin or its analogue cdf. Cancer Res. 2010, 70, 3606-3617. [CrossRef] [PubMed]

108. Giovannetti, E.; Funel, N.; Peters, G.J.; Del Chiaro, M.; Erozenci, L.A.; Vasile, E.; Leon, L.G.; Pollina, L.E.; Groen, A.; Falcone, A.; et al. MicroRNA-21 in pancreatic cancer: Correlation with clinical outcome and pharmacologic aspects underlying its role in the modulation of gemcitabine activity. Cancer Res. 2010, 70, 4528-4538. [CrossRef] [PubMed] 
109. Hwang, J.H.; Voortman, J.; Giovannetti, E.; Steinberg, S.M.; Leon, L.G.; Kim, Y.T.; Funel, N.; Park, J.K.; Kim, M.A.; Kang, G.H.; et al. Identification of microRNA-21 as a biomarker for chemoresistance and clinical outcome following adjuvant therapy in resectable pancreatic cancer. PLoS ONE 2010, 5, e10630. [CrossRef] [PubMed]

110. Moriyama, T.; Ohuchida, K.; Mizumoto, K.; Yu, J.; Sato, N.; Nabae, T.; Takahata, S.; Toma, H.; Nagai, E.; Tanaka, M. MicroRNA-21 modulates biological functions of pancreatic cancer cells including their proliferation, invasion, and chemoresistance. Mol. Cancer Ther. 2009, 8, 1067-1074. [CrossRef] [PubMed]

111. Wang, P.; Zhuang, L.; Zhang, J.; Fan, J.; Luo, J.; Chen, H.; Wang, K.; Liu, L.; Chen, Z.; Meng, Z. The serum mir-21 level serves as a predictor for the chemosensitivity of advanced pancreatic cancer, and mir-21 expression confers chemoresistance by targeting fasl. Mol. Oncol. 2013, 7, 334-345. [CrossRef] [PubMed]

112. Dhillon, N.; Aggarwal, B.B.; Newman, R.A.; Wolff, R.A.; Kunnumakkara, A.B.; Abbruzzese, J.L.; Ng, C.S.; Badmaev, V.; Kurzrock, R. Phase ii trial of curcumin in patients with advanced pancreatic cancer. Clin. Cancer Res. 2008, 14, 4491-4499. [CrossRef] [PubMed]

113. Li, Y.; VandenBoom, T.G., 2nd; Kong, D.; Wang, Z.; Ali, S.; Philip, P.A.; Sarkar, F.H. Up-regulation of mir-200 and let-7 by natural agents leads to the reversal of epithelial-to-mesenchymal transition in gemcitabine-resistant pancreatic cancer cells. Cancer Res. 2009, 69, 6704-6712. [CrossRef] [PubMed]

114. Vietsch, E.E.; van Eijck, C.H.; Wellstein, A. Circulating DNA and micro-RNA in patients with pancreatic cancer. Pancreat. Disord. Ther. 2015, 5. [CrossRef]

115. Frampton, A.E.; Krell, J.; Jamieson, N.B.; Gall, T.M.; Giovannetti, E.; Funel, N.; Mato Prado, M.; Krell, D.; Habib, N.A.; Castellano, L.; et al. MicroRNAs with prognostic significance in pancreatic ductal adenocarcinoma: A meta-analysis. Eur. J. Cancer 2015, 51, 1389-1404. [CrossRef] [PubMed]

116. Zhou, L.; Zhang, W.G.; Wang, D.S.; Tao, K.S.; Song, W.J.; Dou, K.F. MicroRNA-183 is involved in cell proliferation, survival and poor prognosis in pancreatic ductal adenocarcinoma by regulating bmi-1. Oncol. Rep. 2014, 32, 1734-1740. [CrossRef] [PubMed]

117. Baraniskin, A.; Nopel-Dunnebacke, S.; Ahrens, M.; Jensen, S.G.; Zollner, H.; Maghnouj, A.; Wos, A.; Mayerle, J.; Munding, J.; Kost, D.; et al. Circulating u2 small nuclear RNA fragments as a novel diagnostic biomarker for pancreatic and colorectal adenocarcinoma. Int. J. Cancer 2013, 132, E48-E57. [CrossRef] [PubMed]

118. Huang, C.; Yu, W.; Wang, Q.; Cui, H.; Wang, Y.; Zhang, L.; Han, F.; Huang, T. Increased expression of the lncRNA pvt1 is associated with poor prognosis in pancreatic cancer patients. Minerva Med. 2015, 106, 143-149. [PubMed]

119. Kim, K.; Jutooru, I.; Chadalapaka, G.; Johnson, G.; Frank, J.; Burghardt, R.; Kim, S.; Safe, S. Hotair is a negative prognostic factor and exhibits pro-oncogenic activity in pancreatic cancer. Oncogene 2013, 32, 1616-1625. [CrossRef] [PubMed]

120. Pang, E.J.; Yang, R.; Fu, X.B.; Liu, Y.F. Overexpression of long non-coding RNA malat1 is correlated with clinical progression and unfavorable prognosis in pancreatic cancer. Tumour Biol. 2015, 36, $2403-2407$. [CrossRef] [PubMed]

121. Peng, W.; Gao, W.; Feng, J. Long noncoding RNA hulc is a novel biomarker of poor prognosis in patients with pancreatic cancer. Med. Oncol. (Northwood Lond. Engl.) 2014, 31, 346. [CrossRef] [PubMed]

122. Lu, X.; Fang, Y.; Wang, Z.; Xie, J.; Zhan, Q.; Deng, X.; Chen, H.; Jin, J.; Peng, C.; Li, H.; et al. Downregulation of gas5 increases pancreatic cancer cell proliferation by regulating cdk6. Cell Tissue Res. 2013, 354, 891-896. [CrossRef] [PubMed]

(C) 2016 by the authors; licensee MDPI, Basel, Switzerland. This article is an open access article distributed under the terms and conditions of the Creative Commons Attribution (CC-BY) license (http://creativecommons.org/licenses/by/4.0/). 